\title{
Petrology and Geochemistry of Ophiolitic Host Rocks of Copper Mineralization in Dowlat Abad-Tang e Hana Area (Neyriz-Iran)
}

\author{
Pedram Attarzadeh $^{1}$, Mohammad Yazdi², Mehrdad Karimi ${ }^{3}$, Kamal Noori Khankahdani ${ }^{3}$ \\ ${ }^{1}$ Department of Geology, North Tehran Branch, Islamic Azad University, Tehran, Iran \\ ${ }^{2}$ Department of Geology, Faculty of Earth Sciences, Shahid Beheshti University, Tehran, Iran \\ ${ }^{3}$ Department of Geology, Shiraz Branch, Islamic Azad University, Shiraz, Iran \\ Email: *attarzadeh.pedram@yahoo.com
}

Received 19 June 2016; accepted 5 August 2016; published 8 August 2016

Copyright (C) 2016 by authors and Scientific Research Publishing Inc.

This work is licensed under the Creative Commons Attribution International License (CC BY). http://creativecommons.org/licenses/by/4.0/

\section{(c) (1)}

\begin{abstract}
Dowlat Abad-Tang e Hana area is a part of Neyriz ophiolite zone, parallel to the Zagros thrust, SW of Iran. It is also a part of obduction thrusting belt over the edge of the Arabian continent during the late Cretaceous. Petrographic investigation indicates the main host rocks are harzburgite, dunite, pyroxenite, basalt, gabbro and pelagic marine sediments. The main magma type of this ophiolite complex is sub-alkaline. The geochemical data of analysed samples show depletion of $\mathrm{Na}$ and $\mathrm{K}$, and enrichment in Ca. Copper mineralization in Dowlat Abad-Tang e Hana is hosted mainly in peridotite rocks. The mineralizations are vein type and are associated as copper carbonate (malachite and less azurite). The average of $\mathrm{Cu}$ grade is $2.3 \mathrm{wt} \%$. The geochemical and mineralogical data show that the primary source of copper is ortho-magmatic (from ultra-basic rocks and ferro magnesium minerals), which later influenced by hydrothermal processes.
\end{abstract}

\section{Keywords}

Ophiolite, Copper Mineralization, Tang-e-Hana, Neyriz, SW of Iran

\section{Introduction}

Many researches show that ophiolite complexes are formed in different geotectonic positions [1] [2]. The Te-

${ }^{*}$ Corresponding author.

How to cite this paper: Attarzadeh, P., Yazdi, M., Karimi, M. and Khankahdani, K.N. (2016) Petrology and Geochemistry of Ophiolitic Host Rocks of Copper Mineralization in Dowlat Abad-Tang e Hana Area (Neyriz-Iran). Open Journal of Geology, 6, 703-720. http://dx.doi.org/10.4236/ojg.2016.68054 
thyan ophiolites in the Alpine-Himalayan orogenic system are exposed along curvilinear suture zones, bounding a series of continental fragments of Gondowana [3]. The Jurassic ophiolites in the Alpine-Apennine mountain belt in the west (Figure 1) commonly display MORB geochemistry [4] [5], while that Late Jurassic-Cretaceous ophiolites in the Taurid-Pontide (Turkey), Zagros (Iran), and the Himalayan mountain belts to the east show geochemical affinities characteristic of suprasubduction zone (SSZ) environments [3] [6]-[16]. The ophiolitic complexes along Bitlis-Zagros Suture Zone include: Baer-Bassit (Syria), Hataya, Kizildag, and Cilo (Turkey); Kermanshah, Neyriz and Esphandagheh (Iran) [17]-[19]. The ophiolites from Iran may be classified into two groups, the less abundant Paleozoic and the more abundant Mesozoic ophiolites [20]. Stöcklin (1974) [21] divided Iranian ophiolites into four groups: i) ophiolites of the Zagros; ii) ophiolites (coloured melanges) of north-west Iran; iii) ophiolites and coloured mélanges that mark the boundaries of the Central and Eastern Iranian microcontinent [23]; and iv) ophiolites at the northern foot of the Alborz range [22] [23]. Alavi(1991) used information from field relations to classify the Iranian ophiolites into three groups: i) the Proterozoic, which are present as isolated outcrops on the western edge of the central Iranian microcontinent (CIM), ii) the pre Jurassic, which are located within the Alborz Range to the north, and iii) the post-Jurassic, which are the most abundant. Neyriz ophiolite is located in western part of Zagros thrust zone which separates Sanandaj-Sirjan crystalline complexes and Zagros thrust belt [24]. The Zagros fold-and-thrust belt extends in a NW-SE direction from the IranianTurkish border to Gulf of Oman (Figure 1) [25] [26]. This still-active belt results from the collision of the Arabian and Eurasian plates during Cenozoic times and is one of the youngest continental collision belts within the Alpine-Himalayan orogenic system [27] [28]. The geodynamic evolution of the Zagros Belt is mainly related to the opening and closure of the Neo-Tethys Oceanic basin. A Late Permian rift episode led to the opening of the Neo-Tethyan Ocean between the Arabian and Iranian plates. The NE-dipping subduction of this oceanic branch beneath the Iranian continental margin [29], started in the Late Jurassic [30]. The obduction of the oceanic crust began in the Late Cretaceous and was accompanied by a diachronous emplacement of ophiolites on to the southern. Tethyan passive margin, which occurred during Santonian in Oman and Maastrichtian in NW Zagros [31].

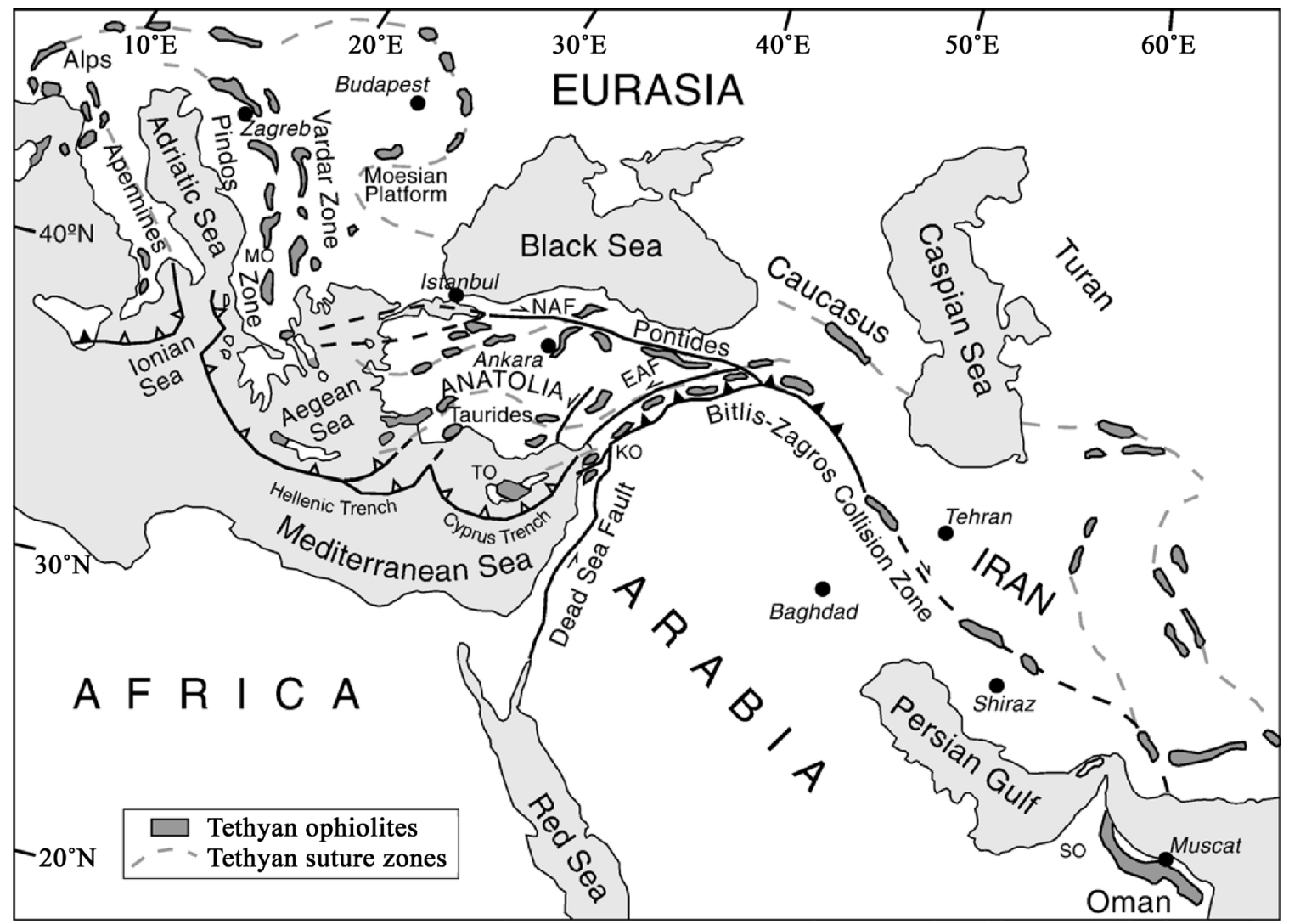

Figure 1. Simplified tectonic map of the eastern Mediterranean region showing the distribution of the Neotethyan ophiolites and suture zones [38]. 
The consumption of the Neo-Tethys and the associated continental collision are recorded by the southern Iranian ophiolites (Kermanshah, Neyriz) (Figure 1), which surface along the Main Zagros Thrust Zone [29] [32] [33]. In general ophiolite belt along the south-western Zagros main Zagros thrust divided into two parts as ophioliteradiolarites of Kermanshah [34] and Neyriz [35] in the Fars [36]. According to spectrometry from biotite-bearing layers in garnet of amphibolite, related to mafic and ultramafic rocks of Neyriz ophiolite, primitive age of ophiolite replacement is middle Jurassic (170 Ma) and metamorphic stage was in last Cretaceous [37]. In this paper, we present results on petrology and geochemistry of the Neyriz ophiolite(Dowlat Abad-Tang e Hana). The goal of this paper is to use field data, petrographic analyses and geochemical data, to i) identify different lithologic units of this complex, ii) shed light on the geochemistry and petrogenetic processes of formation, and iii) suggest a possible tectonic environment of formation for this ophiolite.

\section{Materials and Methods}

\subsection{Geological Setting}

Iranian ophiolites are part of the Tethyan ophiolite belt of the Middle East. They join the Middle Eastern and Mediterranean Hellenides-Dinarides ophiolites (such as Turkish, Troodos, Greek and East European) to more easterly Asian ophiolites (such as Pakistani and Tibetan) [33]. The Neyriz ophiolite, found in a semi-arid environment along the Zargos thrust Zone, SW Iran, is a well-preserved part of the Tethyan oceanic lithosphere [39]. Neyriz ophiolite complex; is located in the north of the Neyriz city; it limits to the eastern Sanandaj-Sirjan zone, and the Bakhtegan Lake to west and the Zagros thrust to south. As structural division, studied area is a part of the high Zagros or crushed zone. An important feature of Zagros crushed zone is severity of deformation and also exposed ophiolite sequence. In the scope of the subject of this study (Dowlat Abad-Tang e Hana) (Figure 2), a series of Neyriz ophiolites observed; Three main ophiolite sections can be seen in this row: frequency of dunite and harzburgite and little chromite which forms the base of this Periodicity. Periodicity of webstrite, lherzolite, clinopyroxenite, olivine-webstrite and a little bit chromite in the middle part of the sequence, and in some articles referred to as the transition region. Section of gabbro is composed of and feldspar-bearing peridotites, from melagabro and norite gabbro, troctolite and anorthosite, respectively in the bottom part and in the middle section ferrogabbros, locogabros and finally in the end is composed of quartz and quartzdiorite and ferodiorite [40]-[43].

\subsection{Analytical Methods}

To evaluate the Eastern range part of Neyriz ophiolite complex (Dowlat Abad-Tang e Hana), after field surveying, the 84 samples selected from host rocks, trenches and wells logs. Thin sections of different rock-types were studied, achieving more information about the petrographic characteristics of the Dowlat Abad-Tang e Hana area. The sections gathered from harzburgite, dunite, chromitite, pyroxenite rock-types. Whole rock major elements of ultramafics and trace elements were determined by X-ray fluorescence (XRF) spectrometer. Also, these samples were analyzed by ICP-OES for REE and minor elements. The measurement results are presented in Table 1 and Table 2.

\section{Results and Discussion}

\subsection{Petrography}

The main host rocks, according to their composition divided into several groups: peridotite, pyroxenite, gabbro, diabase dikes, basaltic rocks, radiolarites, serpentinite [44], small masses of metamorphic rocks, lumps of chromite and magnetite veinlets. The most extensive rocks in Neyriz ophiolite are dunite, harzburgite, pyroxenite, little lherzolite and with norite, gabbro, serpentinite and chromitites often with dunite host rocks and some harzburgite host rocks [45]. Serpentinite alteration of peridotite rocks with varying degrees ( $10 \%$ to $90 \%$ serpentine) has been made. The most abundant rock in the ophiolite complex of Dowlat Abad-Tang e Hana region is harzburgite [46]. Based on abundance of pyroxene, rocks can be divided into two main groups wich are harzburgite (homogeneous) and depleted harzburgite. Harzburgites composed of olivine (55\% - 75\%), orthopyroxene $(30 \%-35 \%)$, clinopyroxene (3\% - 5\%) and chrome-bearing spinel (3\% - 5\%). Depleted harzburgite also contain olivine (60\% - 80\%), orthopyroxene (15\% - 20\%), clinopyroxene (1\% - 3\%) and chrome-bearing spinel (less than 2\%). It is believed that harzburgite is the result of increasing in degrees of partial melting in the upper 
mantle and by evolution of rock lherzolite is formed [47]. In the course of the deep zones to the upper part of ophiolite column, depleted harzburgite the rocks and metamorphic foliation intensity increased and the mineral alteration in the rocks decreases (Figure 3). In this rocks, spinel often forms amorphous to hypidiomorphic and can be seen both the crystalline and the inclusion in olivine crystals (Figure 4 and Figure 5).

\section{Geological map of the Neyriz area}

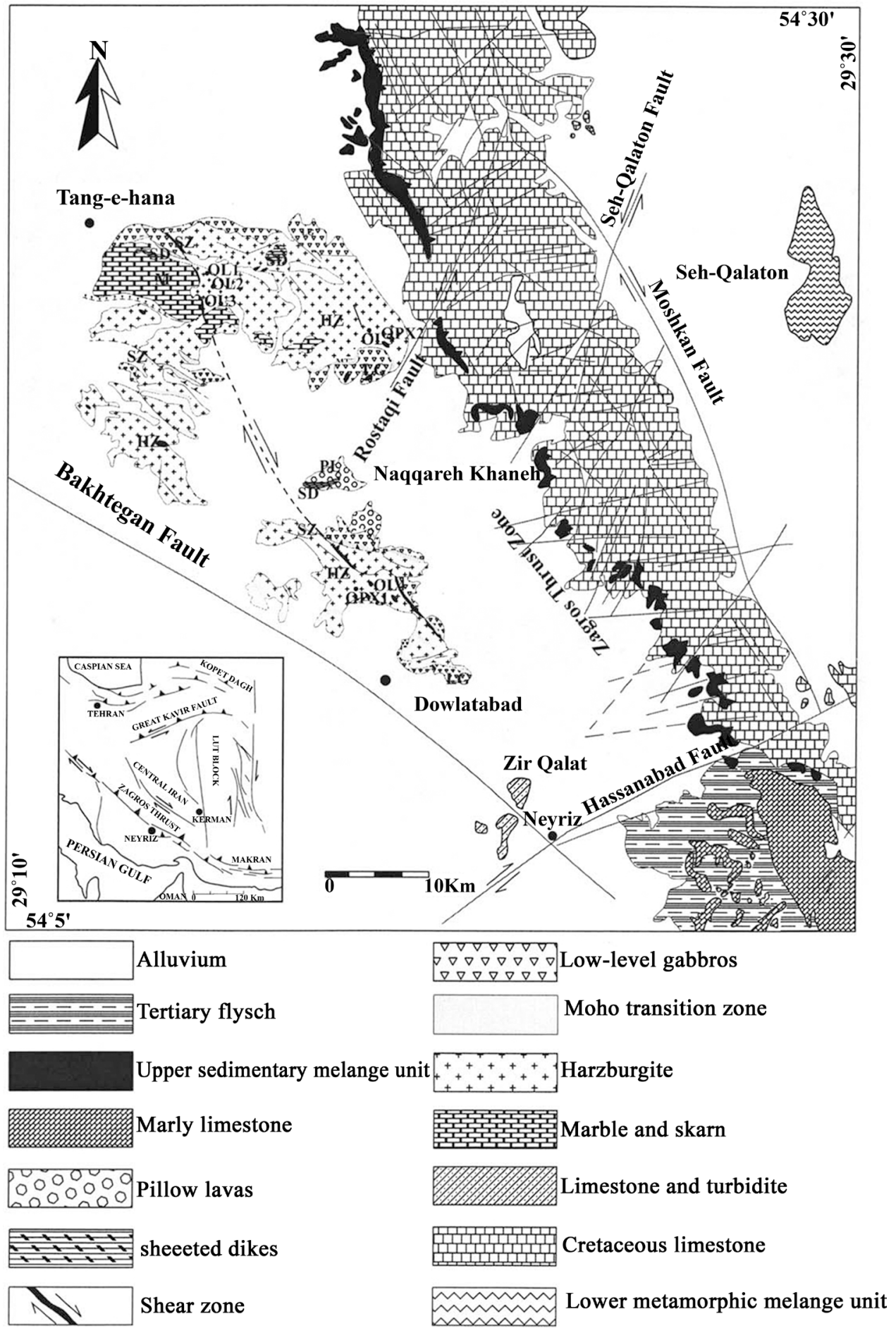

Figure 2. Geological map of Dowlat Abad-Tang e Hana area [39]. 


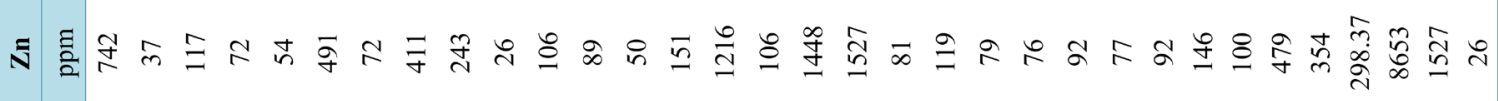

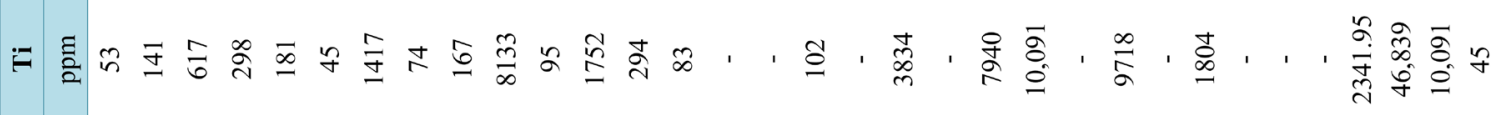

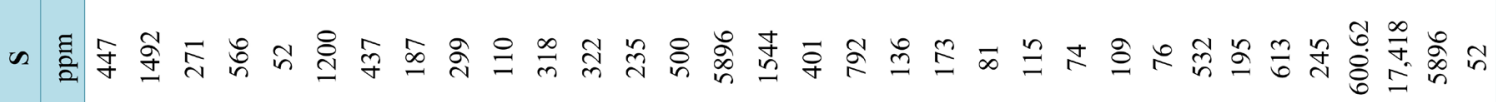

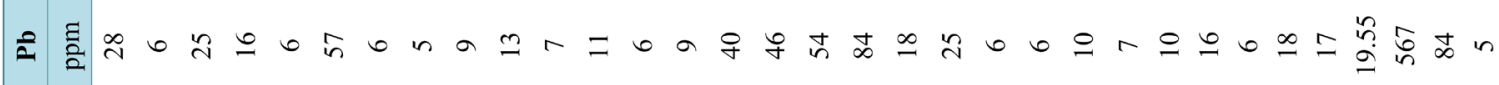

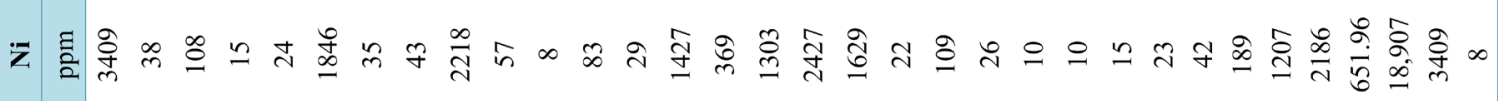

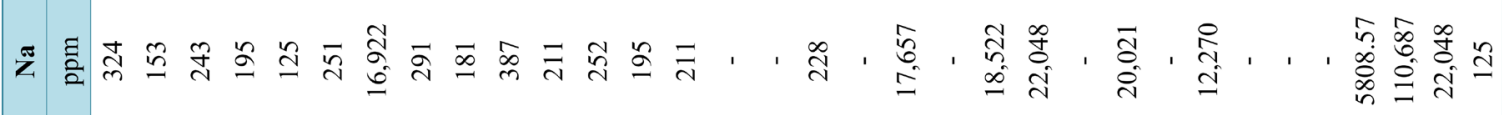
일

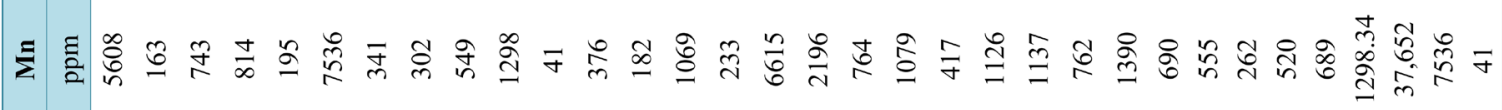

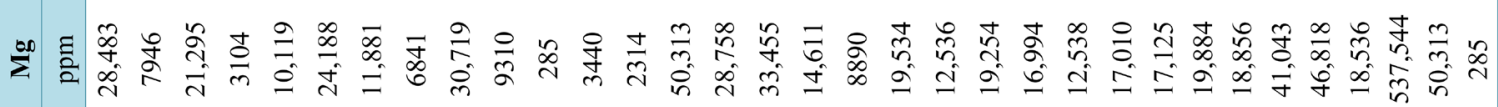

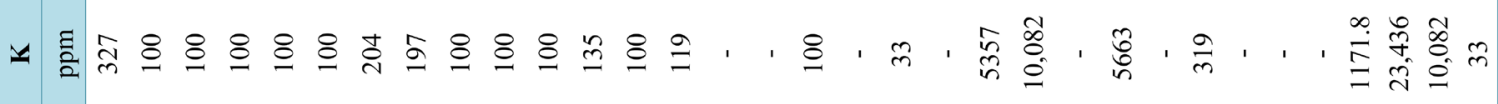

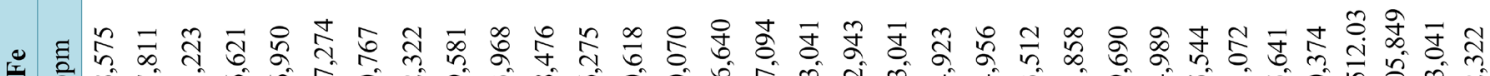

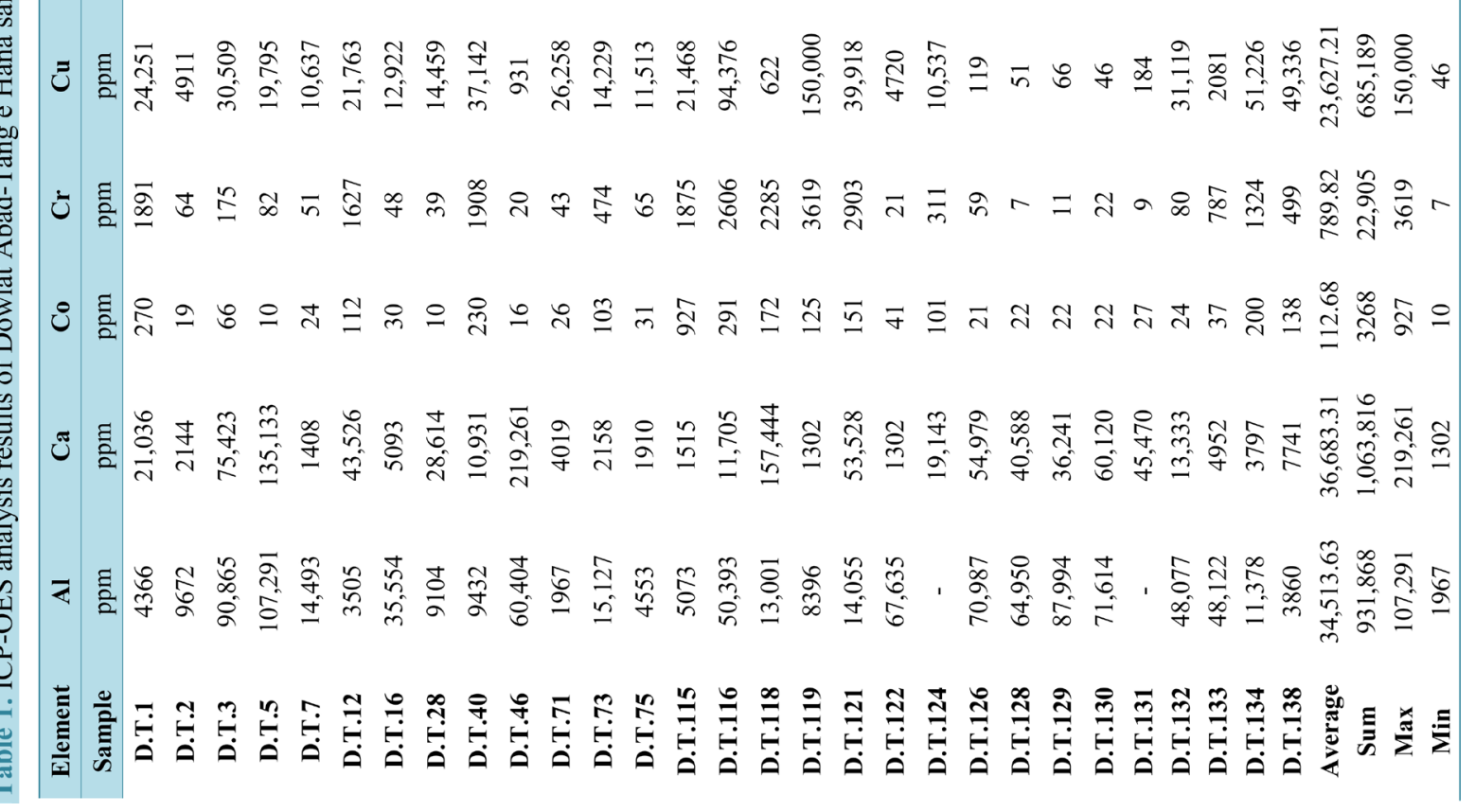


Table 2. XRF analysis results of Dowlat Abad-Tang e Hana samples.

\begin{tabular}{|c|c|c|c|c|c|c|c|c|c|c|c|c|c|}
\hline Element & $\mathrm{SiO}_{2}$ & $\mathrm{Al}_{2} \mathbf{O}_{3}$ & FeO & $\mathrm{Fe}_{2} \mathrm{O}_{3}$ & $\mathrm{CaO}$ & $\mathrm{Na}_{2} \mathrm{O}$ & $\mathrm{K}_{2} \mathrm{O}$ & MgO & $\mathrm{TiO}_{2}$ & MnO & $\mathbf{P}_{2} \mathbf{O}_{5}$ & $\mathrm{SO}_{3}$ & LOI \\
\hline Sample & $\%$ & $\%$ & $\%$ & $\%$ & $\%$ & $\%$ & $\%$ & $\%$ & $\%$ & $\%$ & $\%$ & $\%$ & $\%$ \\
\hline 1 & 39.73 & 0.35 & 8.38 & 1.5 & 0.77 & 0.02 & 0.01 & 37.97 & 0.003 & 0.166 & 0.001 & 0.001 & 10.38 \\
\hline 2 & 40.22 & 0.42 & 8.36 & 1.5 & 0.97 & 0.01 & 0.02 & 36.86 & 0.003 & 0.162 & 0.002 & 0.002 & 10.54 \\
\hline 3 & 38.25 & 0.27 & 7.34 & 1.5 & 0.53 & 0.01 & 0.01 & 39.15 & 0 & 0.164 & 0.002 & 0.001 & 10.94 \\
\hline 4 & 40.21 & 0.48 & 6.34 & 1.5 & 0.8 & 0.01 & 0.02 & 38.23 & 0.001 & 0.154 & 0.002 & 0.002 & 11.58 \\
\hline 5 & 40.11 & 0.26 & 7.81 & 1.5 & 0.65 & - & 0.03 & 39.2 & 0.003 & 0.156 & 0.001 & 0.002 & 9.43 \\
\hline 6 & 40.11 & 0.51 & 7.01 & 1.51 & 0.75 & 0.01 & 0.01 & 38.45 & 0.005 & 0.166 & 0.002 & 0.001 & 10.63 \\
\hline 7 & 37.85 & 0.58 & 9.55 & 1.5 & 0.96 & - & 0.01 & 38.85 & 0.002 & 0.169 & 0.002 & 0.002 & 9.82 \\
\hline 8 & 39.52 & 0.34 & 6.3 & 1.5 & 0.73 & 0.02 & 0.01 & 32.55 & 0.003 & 0.151 & 0.001 & 0.002 & 10.74 \\
\hline 9 & 37.71 & 0.45 & 8.33 & 1.5 & 0.87 & 0.01 & 0.02 & 38.66 & 0.001 & 0.163 & 0.002 & 0.001 & 11.23 \\
\hline 10 & 40.67 & 0.38 & 7.28 & 1.51 & 0.91 & 0.01 & 0.01 & 36.75 & 0.004 & 0.149 & 0.001 & 0.001 & 9.91 \\
\hline 11 & 27.3 & 0.82 & 11.51 & 2.8 & 0.29 & 0.01 & 0.01 & 17.48 & 0.009 & 0.211 & 0.001 & 0.003 & 2.14 \\
\hline 12 & 10.64 & 0.34 & 9.89 & 1.1 & 0.99 & 0.001 & 0.01 & 17.58 & 0.004 & 0.171 & 0.001 & 0.003 & 1.86 \\
\hline 13 & 15.15 & 0.36 & 5.43 & 1.04 & 0.33 & 0.02 & 0.01 & 24.82 & 0.007 & 0.133 & 0.001 & 0.001 & 5.33 \\
\hline Average & 34.42 & 0.42 & 7.96 & 1.53 & 0.73 & 0.01 & 0.01 & 33.58 & 0.003 & 0.16 & 0.001 & 0.001 & 8.81 \\
\hline Sum & 447.47 & 5.56 & 103.53 & 19.96 & 9.55 & 0.131 & 0.18 & 436.55 & 0.045 & 2.115 & 0.019 & 0.022 & 114.53 \\
\hline Max & 40.67 & 0.82 & 11.51 & 2.8 & 0.99 & 0.02 & 0.03 & 39.2 & 0.009 & 0.211 & 0.002 & 0.003 & 11.58 \\
\hline Min & 10.64 & 0.26 & 5.43 & 1.04 & 0.29 & 0 & 0.01 & 17.48 & 0 & 0.133 & 0.001 & 0.001 & 1.86 \\
\hline
\end{tabular}

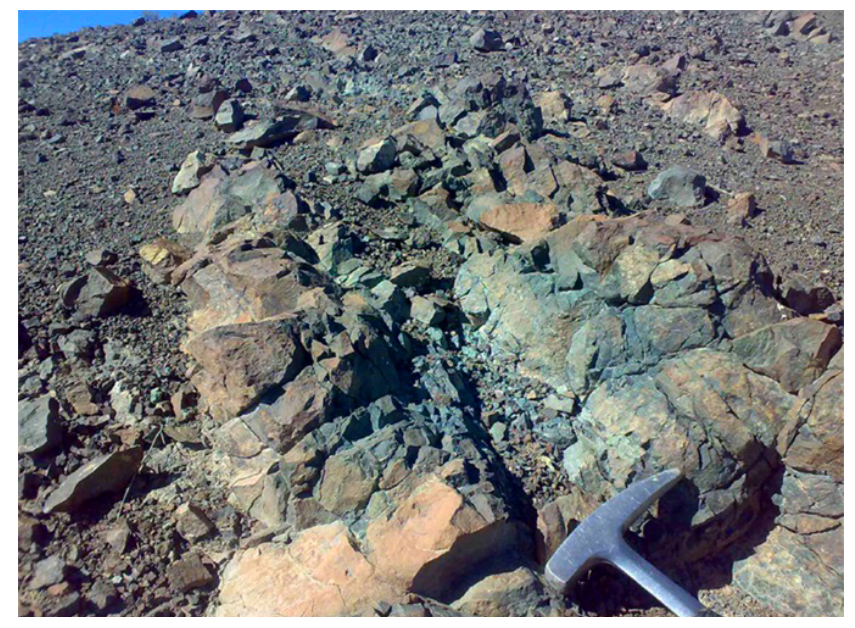

Figure 3. Out cropped harzburgites in Dawlat Abad area.

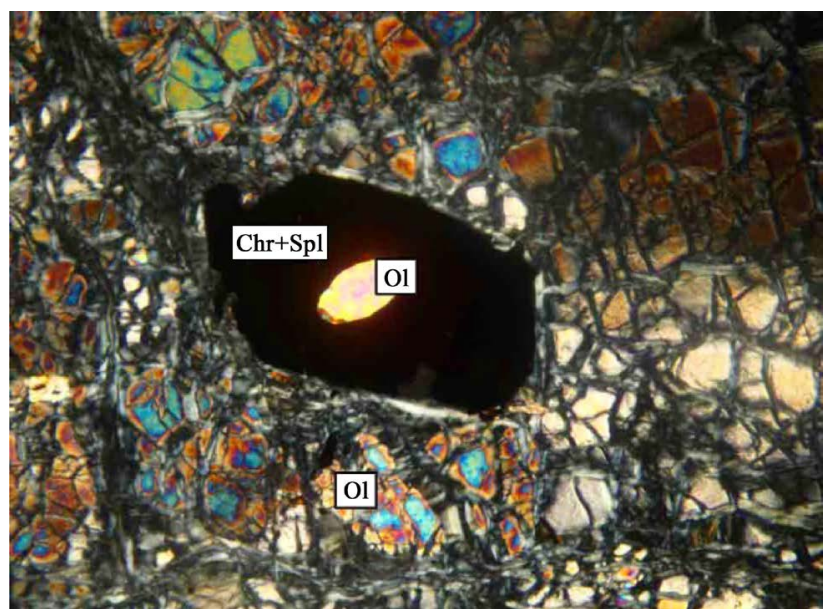

Figure 4. Olivine crystal in a Chromite Spinel $(\mathrm{PPL} \times 200)$. 


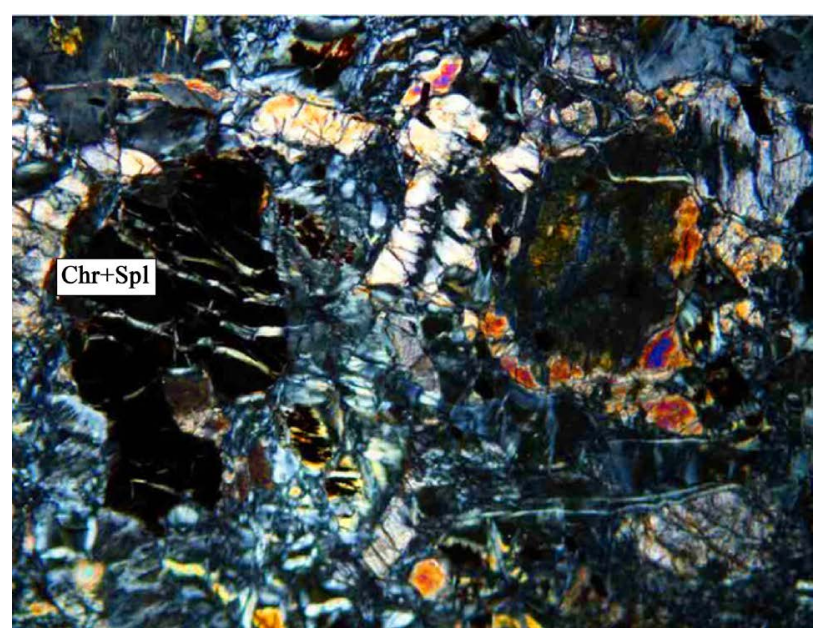

Figure 5. Chromite spinel thin sections $(\mathrm{PPL} \times 200)$.

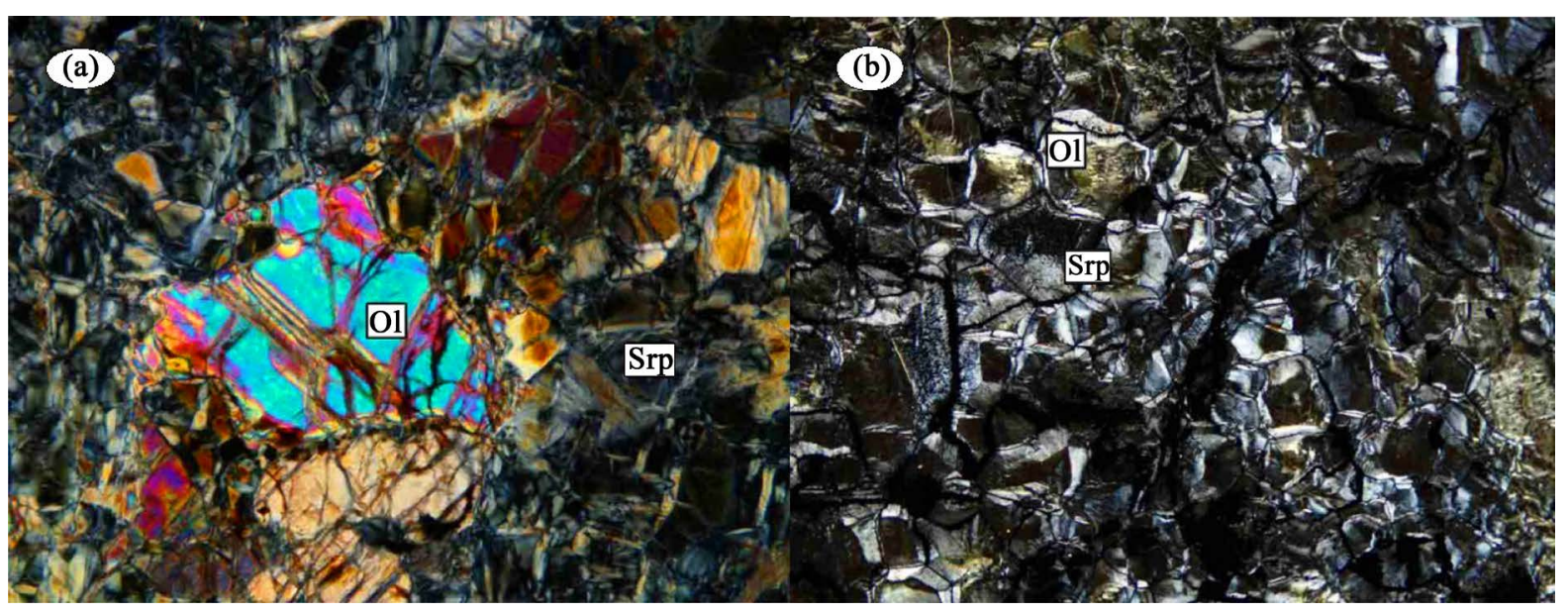

Figure 6. Photomicrographs of thin sections (a) Orthopyroxene thin section bearing dunite (PPL $\times 100)$; (b) Completely serpentinized $(\mathrm{PPL} \times 40)$.

Amount of olivine in dunites increases to more than 90\%. Orthopyroxene changes between 1-8\% and chrome spinel between $1 \%-2 \%$. Clinopyroxene has been completely removed from this rock. Amorphous olivine crystals, sometimes they are hypidiomorphic and crystallized as aggregation and accumulation (Figure 6(a)). Intensity of serpentinized rocks are often very high and usually less altered olivine crystals settled in the field of lizardite (Figure 6(b)).

Orthopyroxenite rock composed of from $0 \%$ - 3\% olivine, more than $95 \%$ orthopyroxene, $0 \%$ - $2 \%$ clinopyroxene and $1 \%-2 \%$ chrome bearing spinel. Orthopyroxene crystal size in orthopyroxenites is much larger than lherzolite and harzburgite and some of them also extend to $3 \mathrm{~mm}$ (Figure 7(a)). However, such as the covering rocks, severe deformation can be seen in this rock as perceived texture in orthopyroxene crystal bar orthopyroxene, yet the minerals are in the same shape and size and the boundaries between crystals, have contact with three 120-degree angle which is an indication that orthopyroxenite units have produced from magma [48]. Orthopyroxenite is almost weathered and contain serpentine group minerals (not sepentinized). Gabbro is Mainly formed of calcium-rich plagioclase feldspar and augite clinopyroxene. Small amounts of olivine and orthopyroxene may also exist in these rocks. Plagioclase in a gabbro has poly synthetic. Plagioclase crystals can be seen as amorphous to hypidiomorphic, also clinopyroxene can be seen as large and semicrystalline crystals in large scale (Figure 7(b)).

\subsection{Geochemistry}

According to Table 1, MgO content is variable between $17.48 \mathrm{wt} \%$ to $39.2 \mathrm{wt} \% . \mathrm{Al}_{2} \mathrm{O}_{3}$ content changes from 
$0.26 \mathrm{wt} \%$ to $0.58 \mathrm{wt} \%$ and $\mathrm{CaO}$ changes from $0.29 \mathrm{wt} \%$ to $0.99 \mathrm{wt} \%$ also $\mathrm{CaO}$ content decreases with the rise of serpentinization [49]. $\mathrm{P}_{2} \mathrm{O}_{5}$ content is subjected to $\mathrm{CaO}$ changes, because phosphorus in magma has a close relation to calcium. $\mathrm{Fe}_{2} \mathrm{O}_{3}, \mathrm{MnO}$ and $\mathrm{TiO}_{2}$ content decreases in result of increasing the amount of $\mathrm{SiO}_{2}$; this represents pyroxene and olivine crystallization from magma. Since the amount of mantle peridotites, Mg\# is considered as an indicator to determine degree of partial melting or mantle depletion [50]; a high proportion of peridotites, Mg\# in the region are expressing a high degree of partial melting [51] [52]. Given that serpentinization cause $\mathrm{MgO}$ values increase and $\mathrm{CaO}$ decreases, it is concluded that Neyriz peridotites are similar to magnesium serpentinized peridotites in the Alpine type ophiolites. In the case of partial melting of incompatible elements such as $\mathrm{Al}$, $\mathrm{Na}$ and $\mathrm{Ti}$ are depleted, while compliant elements such as $\mathrm{Cr}$ and $\mathrm{Ni}$ do not change to the source. Ti depletion in rocks of the area is environmental characteristics of subduction and boninite ophiolite [53] [54]. Neyriz peridotites have lower $\mathrm{Al}_{2} \mathrm{O}_{3}$ content than adjacent ophiolite in Turkey and Iraq [55]. In addition to the low amount content of $\mathrm{Al}_{2} \mathrm{O}_{3}$, Neyriz ophiolites are also very poor in $\mathrm{TiO}_{2}$. One of the resource depleted reasons is forming magma in subduction zones [56]. Looking at the chart $\mathrm{Cr}-\mathrm{Ni}$ (Figure 8) can be concluded that the rocks chemical compositions of the area are within the tholeiitic and komatiietic basalts (rich in $\mathrm{Mg}$ ).

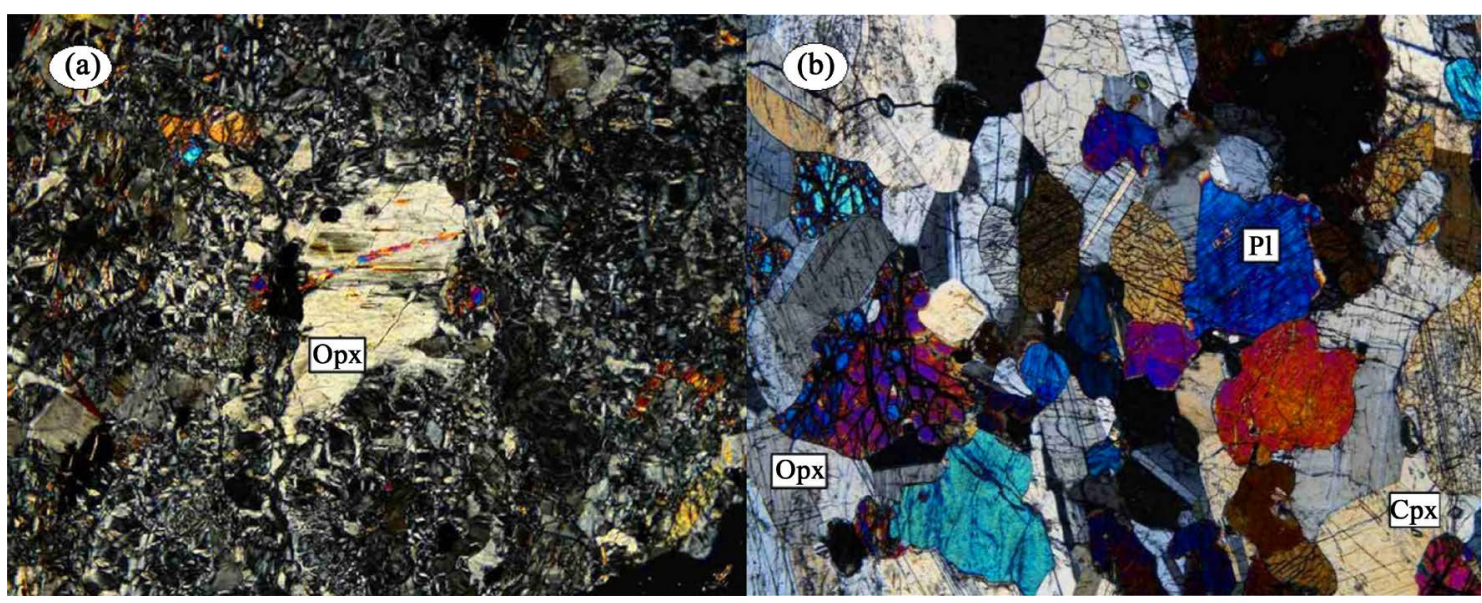

Figure 7. Photomicrographs of thin sections: (a) Orthopyroxene minerals; (b) Plagioclase, orthopyroxene linopyroxene in norite $(\mathrm{PPL} \times 40)$.

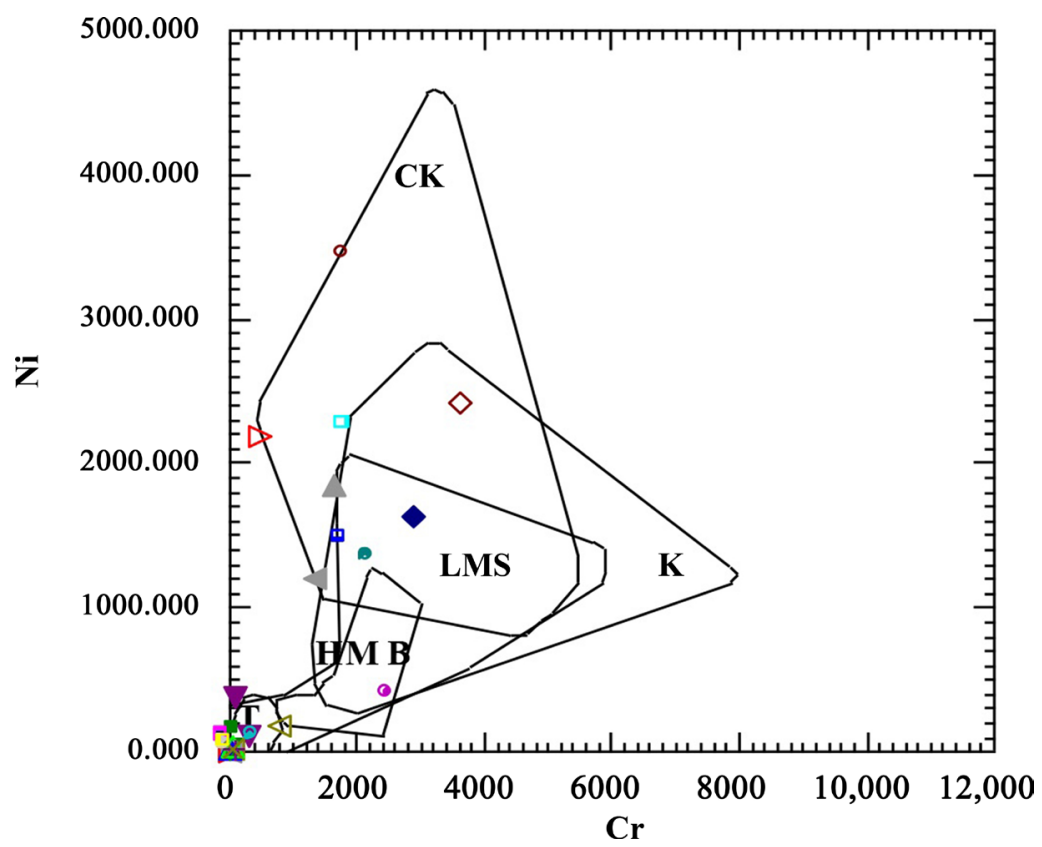

Figure 8. The composition of the rocks of the studied area in the diagram Ni/Cr [Rock et al. 1990]. 
$\mathrm{K}_{2} \mathrm{O}, \mathrm{Na}_{2} \mathrm{O}$ and $\mathrm{SiO}_{2}$ chart (Figure 9) presented the type of magmatic zone as sub-alkaline. Also, the Ti-Cr graph (Figure 10) indicates low-K tholeiite of this kind of magma in the region. Ca-K-Na graph (Figure 11) showing $\mathrm{Na}$ and $\mathrm{K}$ depletion in rocks and enrichment in Ca.

In this (Figure 11), basaltic rocks that contain calcium and sodium minerals are located in Ca-Na pole. This subject indicates that ophiolite complex is formed in a pre-arc subduction zone [59]. In such an environment in the presence of volatile substances by high-grade partial melting, boninitic magnesium-rich magma has formed. The elements such as $\mathrm{Mg}, \mathrm{Ni}$ and $\mathrm{Cr}$ are abundant in the rocks which have produced from this magma. In addition, they are saturated or supersaturated of silica. Being rich in magnesium, abundance of volatiles and satura-

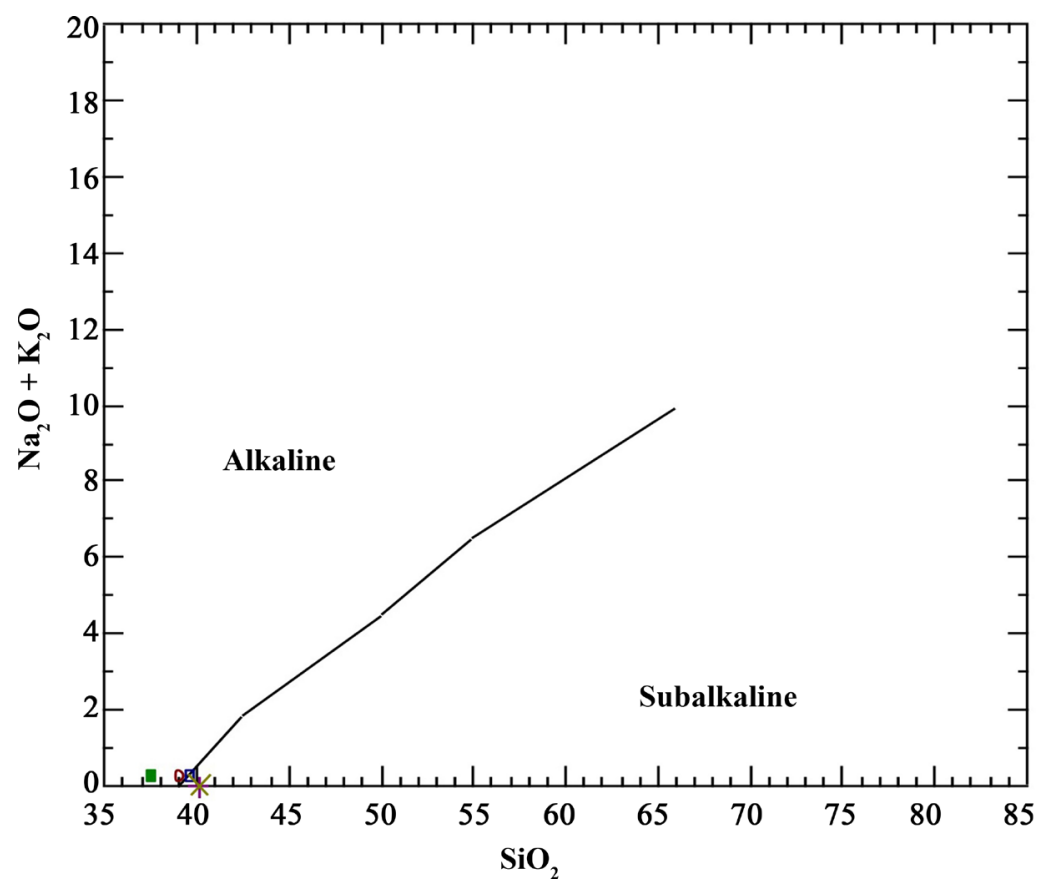

Figure 9. The distinction Naming diagram of basalt [57].

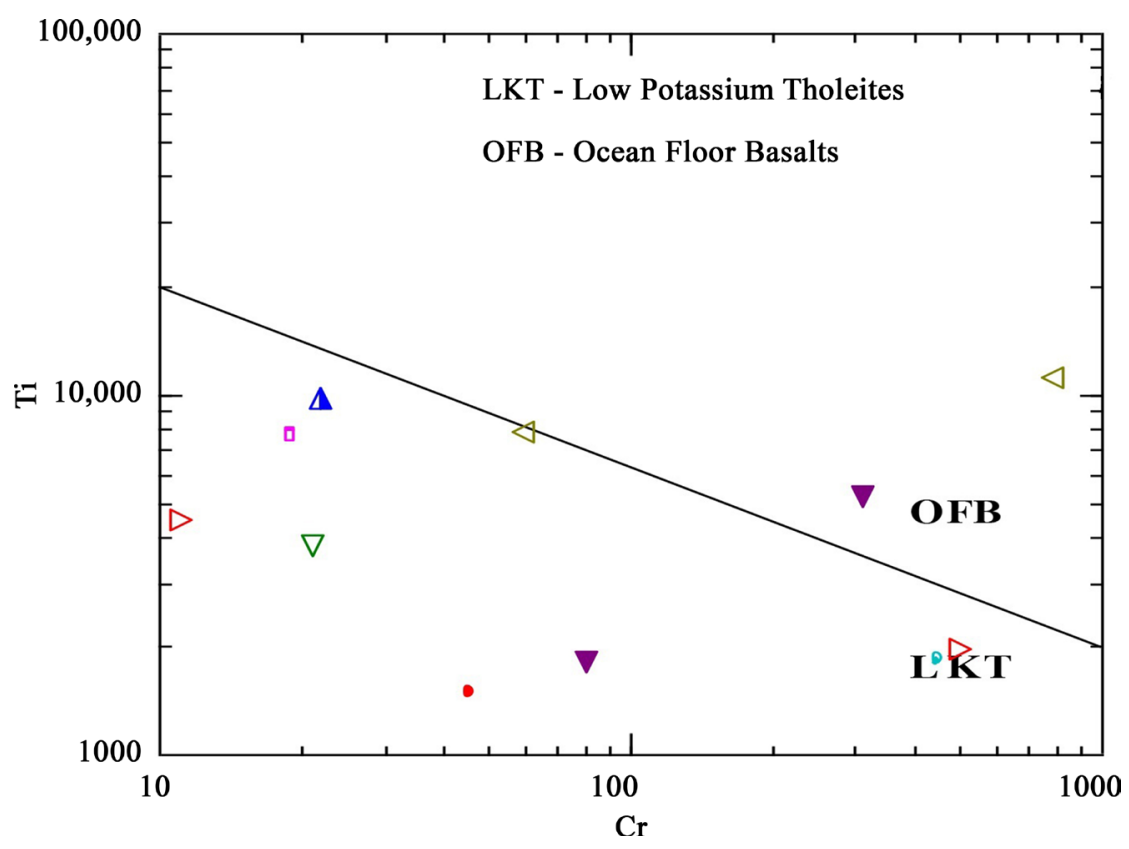

Figure 10. Log Cr-Log Ti [58]. 


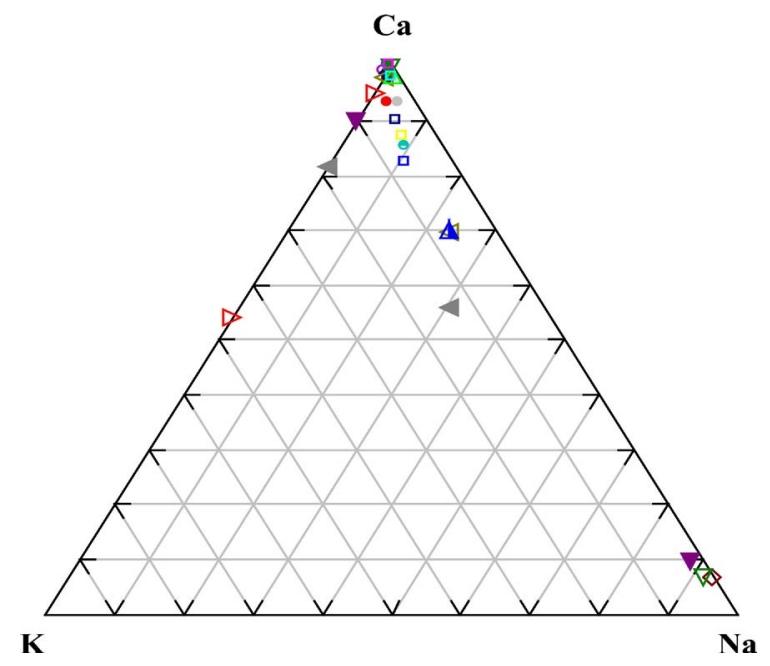

Figure 11. The ophiolite rocks in the study area in diagram of Na-K-Ca.

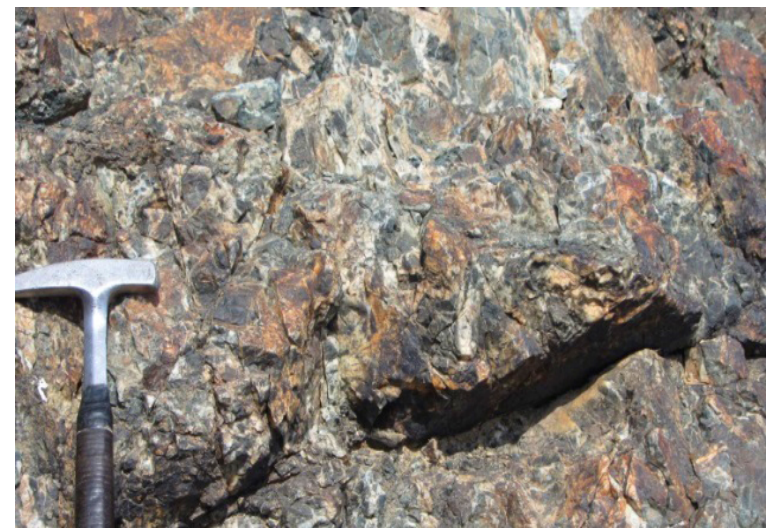

Figure 12. Silicification in Dawlat Abad area.

tion of silica may be contributing factors in the spread of silica and chlorite alteration and the presence of abundant silica and quartz masses in the study area. Along with copper mineralization within Dowlat Abad-Tang e Hana, there are high dispersion masses of silica and silicification alteration (Figure 12).

Extention of silica masses of the area cause acidic nature of altered fluid and as a result of destruction condition of silicate and ferromagnesian minerals, listonits are formed. Also these solutions cause copper washed out of primary copper minerals such as chalcopyrite and pyrite or supergene minerals, soluble copper in oxidation zone in presence of carbonate minerals cause to form malachite and azurite, which has spread throughout the region; among metals, copper shows supergene enrichment more significant than the other metals. Based on the ICP-OES analysis (Table 1), average copper cutie in the Dowlat Abad-Tang e Hana range reaches up to 2.3 by weight percentage.

In the other hand, the study area is situated in Zagros fold and thrust belt. From tectonics point of view, it contains orogenic belt of Arabian plate. Based on previous work on the salt and mud diapirism [60]-[74] and neotectonic regime in Iran [75]-[80], Zagros is the most active zone [81]-[101]. Then, Alborz [102]-[150] and Central Iran [151]-[168] have been situated in the next orders.

\section{Conclusion}

The rocks of the Neyriz ophiolite include both rocks of the mantle and of the crustal suite. The mantle rocks are peridotites (dunite and harzburgite) and serpentinite with minor chromitites. The crustal rocks are cumulate gabbros, diorites, pillow and massive basalts as well as asequence of fossiliferous pelagic sedimentary rocks including umber and radiolarian chert. Harzburgite is observed in the most part of the area (Dowlat Abad-Tang e 
Hana) and occasionally accompanied with small dunite lenses. The major and trace-element geochemical results indicate that Neyriz ophiolite formed from sub-alkaline magma, tholeiitic-komatiietic type and low in K, Na and Ca-Mg-rich. This type of magmas is typical for subduction zone. Ti depletion in rocks of the area is environmental characteristics of subduction and boninite ophiolite. These characteristics are similar to other Tethyan ophiolites along the seam suture zone-Zagros (Bitlis-Zagros suture zone) are exposed. Mg-rich magma and the abundance of volatiles and saturation of silica made pervasive serpentinization, silica and chlorite alteration in the region. The hydrothermal processes were destructed ferromagnesian minerals of ultramafic host rocks and make fair conditions for $\mathrm{Cu}$-mineralization. Although the $\mathrm{Cu}$-mineralization average is high but it does not seem economic deposit.

\section{References}

[1] Dare, S.A.S., Pearce, J.A., McDonad, I. and Styles, M.T. (2009) Tectonic Discrimination of Peidotites Using fO2-Crno. and Ga-Ti-Fe3 Systematics in Chrome-Spinel. Chemical Geology, 261, 199-216. http://dx.doi.org/10.1016/j.chemgeo.2008.08.002

[2] Morishit, T., Maeda, J., Miyashita, S., Kumagai, H., Matsumoto, T. and Dick, H.J.B. (2007) Petrology of Local Concentration of Chromian Spinel in Dunit from the Sliw Spreading Southwest Indian Ridge. European Journal of Mineralogy, 19, 871-882. http://dx.doi.org/10.1127/0935-1221/2007/0019-1773

[3] Dilek, Y., Furnes, H. and Shallo, M. (2008) Geochemistry of the Jurassic Mirdita Ophiolite (Albania) and the MORB to SSZ Evolution of a Marginal Basin Oceanic Crust. Lithos, 100, 174-209. http://dx.doi.org/10.1016/j.lithos.2007.06.026

[4] Tribuzio, R., Tiepolo, M., Vannucci, R. and Bottazzi, P. (1999) Trace Element Distribution within the Olivine-Bearing Gabbros from the Northern Apennine Ophiolites (Italy): Evidence for Post-Cumulus Crystallization in MOR-Type Gabbroic Roks. Contributions to Mineralogy and Petrology, 134, 123-133. http://dx.doi.org/10.1007/s004100050473

[5] Rampone, E. and Piccardo, G.B. (2000) The Ophiolite-Ocenic Lithosphere Analogue: New Insights from the Northern Apennines (Italy). In: Dilek. Y., Moores, E.M. and Elthon, D., Eds., Crust: New Insights from Field Studirs and the Ocean Drilling Program, Geological Society of America Special Paper, 349, 21-34. http://dx.doi.org/10.1130/0-8137-2349-3.21

[6] Pearce, J.A., Alabaster, T., Shelton, A.W. and Searle, M.P. (1981) The Oman Ophiolite as a Cretaceous Arc-Basin Complex: Evidence and Implications. Philosophical Transactions of the Royal Socity of London, 300, 299-317. http://dx.doi.org/10.1098/rsta.1981.0066

[7] Pearce, J.A., Lippard, S.J. and Roberts, S. (1984) Characteristics and Tectonic Significance of Supra-Subduction Zone Ophiolites. In: Kokelaar, B.P. and Howells, M.F., Eds., Marginal Basin, Geology Society of London Special Publication, 16, 77-89. http://dx.doi.org/10.1144/GSL.SP.1984.016.01.06

[8] Hebert, R. and Laurent, R. (1989) The Mineralogical Study of a Cross-Section through the Plutonic Part of the Troodos Ophiolite: New Constraints for Genesis of Arc-Type Ophiolite. In: Malpas, J., et al., Eds., Ophiolites-Oceanic Crustal Analogues. Proceedings of the Symposium “Troodos 1987”: Nicosia, Cyprus Geological Survey, 149-164.

[9] Arvin, M. (1990) Petrology and Geochemistry of Ophiolites and Associated Rocks from the Zagros Suture, Neyriz. Iran. In: Malpas, J., Moores, E.M., Panayiotou, A. and Xenophontos, C., Eds., Ophiolites, Oceanic Crustal Analogues. Proceedings of the Symposium “Troodos 1987”, Geological Survey Department, Nicosia, 351-365.

[10] Rabinson, P.T. and Malpas, J. (1990) The Troodos Ophiolite of Cyprus: New Perspectives on Its Origin and Emplacement. In: Malpas, J., Moores, E.M., Panayiotou, A. and Xenophontos, C., Eds., Ophiolites of the Symposium "Troodos 1987”, The Geological Survey Department, Nicosia, 13-26.

[11] Hassanipak, A.A. and Ghazi, A.M. (2000) Petrology, Geochemistry and Tectonic Setting of the Khoy Ophiolite, Northwest Iran: Implications for Tethyan Tectonics. Journal of Asian Earth Sciences, 18, 109-121. http://dx.doi.org/10.1016/S1367-9120(99)00023-1

[12] Hebert, R., Huot, F., Wang, C. and Liu, Z. (2003) Yarlung Zangbo Ophiolites (Southern Tibet) Revisited: Geodynamic Implications from the Mineral Record. In: Dilek, Y. and Robinson, P.T., Eds., Ophiolites in Earth History, Geology Society of London Special Publication, 218, 165-190. http://dx.doi.org/10.1144/GSL.SP.2003.218.01.10

[13] Malpas, J., Zhou, M.F., Robinson, P.T. and Reynolds, P.H. (2003) Geochemical and Geochronological Constraints on the Origin and Emplacement of the Yarlung Zangbo Ophiolites, Southern Tibet. In: Dilek, Y. and Robinson, P.T., Eds., Ophiolites in Earth History, Geological Society of London Special Publication, 218, 191-206. http://dx.doi.org/10.1144/GSL.SP.2003.218.01.11

[14] Parlak, O., Hoeck, V., Kozlu, H. and Delaloye, M. (2006) Oceanic Crust Generation in an Island Arc Tectonic Setting, SE Anatolian Orogenic Belt (Turkey). Geological Magazine, 141, 583-603. 
http://dx.doi.org/10.1017/S0016756804009458

[15] Shafaii Moghadam, H. and Stern, R.J. (2011) Geodynamic Evolution of Upper Cretaceous Zagros Ophiolites: Formation of Oceanic Lithosphere above a Nascent Subduction Zone. Geoloical Magazine, 148, 762-801. http://dx.doi.org/10.1017/S0016756811000410

[16] Kiani, M., Ahmadi, K.A., Kamali, Z. and Shafaii, M.H. (2015) Geochemistry of Diabasic Dikes and Andesitic-Basaltic Lavas in Noorabad-Kermanshah Ophiolite. Journal of Tethys, 3, 1-15.

[17] Moores, E.M., Robinson, P.T., Malaps, J. and Xenophonotos, C. (1984) Model for the Origin of the Troodos Massif, Cyprus, and Other Mid-East Ophiolites. Geology, 12, 500-503. http://dx.doi.org/10.1130/0091-7613(1984)12<500:MFTOOT>2.0.CO;2

[18] Dilek, Y. and Moores, E.M. (1987) Regional Tectonics of the Eastern Mediterranean Ophiolites. In: Malpas, J., Moores, E.M., Panayiotou, A. and Xenophontos, C., Eds., Ophiolites, Oceanic Crustal Analogues. Proceedings of the Symposium “Troodos 1987”, Geological Survey Department, Nicosia, 295-309.

[19] Dilek, Y. and Delaloye, M. (1992) Structure of the Kizildag Ophiolite. A Slow-Spread Cretaceous Ridge Segment North of the Arabian Promontory. Geology, 20, 19-22. http://dx.doi.org/10.1130/0091-7613(1992)020<0019:SOTKOA>2.3.CO;2

[20] Alavi, M. (1991) Tectonic Map of the Middle East. Geological Survey of Iran.

[21] Stöcklin, J. (1974) Possible Ancient Continental Margins in Iran. In: Burke, C.A. and Drake, C.L., Eds., The Geology of Continental Margins, Springer, Berlin, 873-887. http://dx.doi.org/10.1007/978-3-662-01141-6_64

[22] Torkian, A., Daraiezadeh, Z., Aliani, F. and Noghreian, M. (2013) The Use of Geochemical Data, Kermanshah Ophiolite Diabase Dykes (The Sahne-Harsin) in Determining the Tectonic Them. Journal of Crystallography and Mineralogy of Iran, No. 2, 331-342.

[23] Takin, M. (1972) Iranian Geology and Continental Drift in the Middle East. Nature, 235, 147-150. http://dx.doi.org/10.1038/235147a0

[24] Shahrestani, S. and Alinia, F. (2013) Platinum Group Elements Geochemistry and Composition of Podiform Chromitites from Khaje Jamali Ophiolite Complex, Neyriz, Southern Iran. Journal of Tethys, 1, 96-112.

[25] Allahyari, K., Saccani, E., Pourmoafi, M., Beccaluva, L. and Masoudi, F. (2010) Perrology of Mantle Peridotites and Intrusive Mafic Rocks from the Kermanshah Ophiolitic Complex (Zagros Belt, Iran): Implications for the Geodynamic Evolution of Neo-Tethyan Oceanic Branch between Arabia and Iran. Ofioliti, 35, 71-90.

[26] Shafaii Moghdam, H., Stern, R.J., Kimura, J.I., Hirahara, Y., Senda, R. and Miyazaki, T. (2012) Hf-Nd Isotope Constraints on the Origin of Dehshir Ophiolite, Central Iran. Island Arc, 21, 202-214. http://dx.doi.org/10.1111/j.1440-1738.2012.00815.x

[27] Ricou, L.E. (1976) Evolution structuralke des Zagrides. La région clef de Neyriz (Zagros iranien). Mem. Soc. géol. France N.S., 55, 125, 140 p.

[28] Ricou, L.E., Braud, J. and Brunn, J.H. (1977) Le Zagros. Livre à la mémoire de A.F de Lapparent, Soc. Géol. France, Paris, 33-52.

[29] Berberian, M. and King, G.C.P. (1981) Towards a Paleogeography and Tectonic Evolution of Iran. Canadian Journal of Earth Sciences, 18, 210-265. http://dx.doi.org/10.1139/e81-019

[30] Stampfli, G.M. and Borel, G.D. (2002) A Plate Tectonic Model for the Paleozoic and Mesozoic Constrained by Dynamic Plate Boundaries and Restored Synthetic Oceanic Isochrons. Earth and Planetary Science Letters, 196, 17-33. http://dx.doi.org/10.1016/S0012-821X(01)00588-X

[31] Leturmy, P. and Robin, C. (2010) Tectonic and Stratigraphic Evolution of Zagros and Makran during the Mesozoic-Cenozoic: Introduction. In: Leturmy, P. and Robin, C., Eds., Tectonic and Stratigraphic Evolution of Zagros and Makran during the Mesozoic-Cenozoic, Vol. 330, Geological Society, London, Special Publications 2010, 1-4.

[32] Stöcklin, J. (1977) Structural Correlation of the Alpine Ranges between Iran and Central Asia. Mémoires de la Société Géologique de France, 8, 333-353.

[33] Alavi, M. (1994) Tectonics of the Zagros Orogenic Belt of Iran: New Data and Interpretations. Tectonophysics, 229, 211-238. http://dx.doi.org/10.1016/0040-1951(94)90030-2

[34] Golonka, J. (2000) Plate Tectonic Map of the Phanerozoic. Special Publications (SEPM), No. 72, 21-75.

[35] Ricou, L.E. (1971) Le metamorphism au contact des peridotits de Neyiz (Zagros Interne, Iran). Development de skarn a pyroxene. Bulletin of the Society of Geology, 13, 146-155.

[36] Mousavi, A., Aliani, F., Maanijoo, M. and Sepahigero, A.A. (2013) Petrology and Geochemistry of Mafic Pillow Lavas and Rocks, Intermediate and Felsic Its Affiliates in the Ophiolite Sequence Sahneh-Harsin (North-East of Kermanshah). Journal of Crystallography and Mineralogy of Iran, No. 2, 253-266. 
[37] Haynes, S.J. and Reynolds, P.H. (1980) Early Development of Tethys and Jurassic Ophiolite Displacement. Nature, 283, 561-563. http://dx.doi.org/10.1038/283561a0

[38] Dilek, Y., Furnes, H. and Shallo, M. (2007) Suprasubduction Zone Ophiolite Formation along the Periphery of Mesozoic Gondwana. Gondwana Research, 11, 453-475. http://dx.doi.org/10.1016/j.gr.2007.01.005

[39] Sarkarinejad, K. (2005) Structures and Microstructures Related to Steady-State Mantle Flow in the Neyriz Ophiolite, Iran. Journal of Asian Earth Sciences, 25, 859-881. http://dx.doi.org/10.1016/j.jseaes.2004.08.007

[40] Falcon, N.L. (1967) The Geology of the Northeast Margin of the Arabian Basement Shield. Advancement of Science, 24, 31-42.

[41] Ricou, L.E. (1974) Letude geologiqes de la region de neyriz (Zagros Iraniaen) et levolution structuraldes zagride. These Universite, Paris, 300.

[42] Nabavi, M.H. (1976) History of Iran Geology, Geological Survey and Mineral Exploration Country. 109 p.

[43] Sabzehei, M. (1996) Geological Map of the Neyriz. Geological Quadrangle Map 1\100000, No. 6848, Geological Survey of Iran. (In Persian)

[44] Sheikhi Karizaki, H. (2006) Ophiolite Rocks Khajeh Jamali Area (Shiraz) and Its Chromite Deposits. Geological and Mineral Exploration Country, 164 p.

[45] Karimi, M., Hosseini, Z. and Noori, K. (2016) Geochemical Distribution of Major, Trace and Rare Elements in Chromite Ores of Neyriz Ophiolite. Iranian Journal of Crystallography and Mineralogy, No. 1, 45-56.

[46] Davoodi, Z., Rahgoshai, M. and Monsef, I. (2014) Geochemistry and Petrogenesis of Peridotites Ophiolite Complex Neyriz (South West of Iran). Journal of Petrology, No. 19, 53-66.

[47] Coleman, R.G. (1977) Ophiolites: Ancient Oceanic Lithosphere? Springer, Berlin, 229 p. http://dx.doi.org/10.1007/978-3-642-66673-5

[48] Berliy, T.J., Hermann, J., Arculus, A.J. and Lapierr, H. (2006) Supra-Subduction Zone Pyroxenites from San Jorge and Santa Isabel (Solomon Islands). Journal of Petrology, 47, 1531-1555. http://dx.doi.org/10.1093/petrology/egl019

[49] Shelley, D. (1993) Igneous and Metamorphic Rocks under the Microscope. Chapman and Hall, London.

[50] Coleman, R.G. and Keith, T.E. (1971) A Chemical Study of Serpentinization Burro Mountain, California. Journal of Petrology, 12, 311-328. http://dx.doi.org/10.1093/petrology/12.2.311

[51] Nicolas, A. and Prinzhofer, A. (1983) Cumulative or Residual Origin for the Transition Zones in Ophiolites, Structural Evidence. Journal of Petrology, 24, 188-206. http://dx.doi.org/10.1093/petrology/24.2.188

[52] Hartmann, G. and Wedepohl, K.H. (1993) The Composition of Peridotite Tectonites from the Ivrea Complex, Northern Italy: Residues from Melt Extraction. Geochimica et Cosmochimica Acta, 57, 1761-1782. http://dx.doi.org/10.1016/0016-7037(93)90112-A

[53] Pearce, J.A., Harris, N.B. and Tindle, A.G. (1984) Trace Element Discrimination Diagrams for the Tectonic Interpretation of Granitic Rocks. Journal of Petrology, 25, 956-983. http://dx.doi.org/10.1093/petrology/25.4.956

[54] Page, Ph., Bedard, J.H. and Tremblay, A. (2009) Geochemical Variations in a Depleted Fore-Arc Mantle: The Ordovician Thetford Mines Ophiolite. Lithos, 113, 21-47. http://dx.doi.org/10.1016/j.lithos.2009.03.030

[55] Roberts, S. (1992) Influence of the Partial Melting Regime on the Formation of Ophiolitic Chromitite. Geological Society of London, 60, 203-217.

[56] Xia, B., Yu, H.X., Mei, H.J., Chen, G.W. and Qi, L. (2003) Geochemistry of Basalts: Evidence for Formation of Dazhu Ophiolite, Tibet (China), in a Supra Subduction Zone Environment. Journal of Geological Society of India, 61, 7-15.

[57] Irvine, T.N. and Baragar, W.R.A. (1971) A Guide to the Chemical Classification of the Common Volcanic Rocks. Canadian Journal of Earth Science, 8, 523-548.

[58] Pearce, J.A. (1975) Basalt Geochemistry Used to Investigate Past Tectonic Environment on Cyprus. Tectonophysics, 25, 41-67. http://dx.doi.org/10.1016/0040-1951(75)90010-4

[59] Babaie, H.A., Babaie, A.A., Ghazi, M. and Arvin, M. (2006) Geochemical, ${ }^{40} \mathrm{Ar} /{ }^{39} \mathrm{Ar}$ Age, and Isotopic Data for Crustal Rocks of the Neyriz Ophiolite, Iran. Canada Journal of Earth Sciences, 43, 57-70. http://dx.doi.org/10.1139/e05-111

[60] Arian, M. (2011) A Preface on Salt Diapirism of Iran. Asar Nafis Press, Qum, 309 p.

[61] Arian, M. and Noroozpour, H. (2015) The Biggest Salt-Tongue Canopy of Central Iran. Open Journal of Geology, 5, 55-60. http://dx.doi.org/10.4236/ojg.2015.52005

[62] Asadian, F., Pourkermani, M. and Arian, M. (2007) Tectonic Geomorphology of Salt Structures in the GarmsarLasjerd Area. Geographical Research, 39, 75-84.

[63] Pourkermani, M. and Arian, M. (1997) Salt Domes of Central Iran. Journal of Humanities, 3, 29-41. 
[64] Arian, M. (2012) Salt Diapirism and Tectonics. 2nd Edition, Asar Nafis Press, Qum, 319 p.

[65] Arian, M. and Noroozpour, H. (2015) Tectonic Geomorphology of Iran’s Salt Structures. Open Journal of Geology, 5, 61-72. http://dx.doi.org/10.4236/ojg.2015.52006

[66] Asadian, F. and Arian, M. (2009) Identification of Diapiric Provinces of Central Iran through Geological and Geographical Analysis. International Journal of Agriculture Environment \& Biotechnology, 2, 3443-3451.

[67] Arian, M. (2012) Clustering of Diapiric Provinces in the Central Iran Basin. Carbonates and Evaporites, 27, 9-18. http://dx.doi.org/10.1007/s13146-011-0079-9

[68] Khodabakhshnezhad, A. and Arian, M. (2016) Salt Tectonics in the Southern Iran. International Journal of Geosciences, 7, 367-377. http://dx.doi.org/10.4236/ijg.2016.73029

[69] Arian, M. (2010) Tectonics and Sedimentation. Farazamin Press, Tehran, 307 p.

[70] Arian, M. and Maleki, Z. (2010) Principals of Experimental Tectonics. Asar Nafis Publication, Qum, 224 p.

[71] Pourkermani, M. and Arian, M. (1998) Tectonic Geomorphology of Salt Domes in West of Zanjan Province, Iran. Geographical Research, 47, 44-53.

[72] Arian, M. and Feizi, F. (2010) The Significance of Faulting on the Surficial Spreading of Evaporitic Deposits in the Varamin-Semnan Area. Journal of Earth and Resources, 3, 1-20.

[73] Feizi, F., Arian, M. and Arian, A. (2015) Mud Diapirism on the Makran, Iran: Case Study on the Napag Mud Volcano. Open Journal of Geology, 5, 300-308. http://dx.doi.org/10.4236/ojg.2015.55027

[74] Arian, M. and Sistanipour, A. (2015) Mud Diapirism on the Gorgan. North Iran Open Journal of Geology, 5, $442-450$. http://dx.doi.org/10.4236/ojg.2015.56041

[75] Arian, M. and Khodabakhshnezhad, A. (2015) Sedimentary Environments Can Be Changed by Geotechnology (Case Study: A Morphotectonic Idea for Design of Extensive Artificial Bay on the Iranian Plateau). International Journal of Geosciences, 6, 487-496. http://dx.doi.org/10.4236/ijg.2015.65039

[76] Arian, M. (2011) Middle East Tectonics. Asar Nafis Press, Qum, 236 p.

[77] Arian, M. (2010) Applied Seismotectonics. Farazamin Press, Tehran, 304 p.

[78] Arian, M. and Maleki, R. (2008) Neotectonics. Farazamin Research Center, Tehran, 150.

[79] Pourkermani, M. and Arian, M. (1998) Seismicity of Iran. Shahid Beheshti University Press, Tehran, 212.

[80] Pourkermani, M. and Arian, M. (1997) Seismotectonics. DezAb Consulting Engineers Company Press, Tehran, 270.

[81] Arian, M. and Aram, Z. (2014) Relative Tectonic Activity Classification in the Kermanshah Area, Western Iran. Solid Earth, 5, 1277-1291. http://dx.doi.org/10.5194/se-5-1277-2014

[82] Mashal, M., PourKermani, M., Charchi, A., Almasian, M. and Arian, M. (2013) Pattern of Structural Geology Underground in Eastern of North Dezfol Embayment. Advances in Environmental Biology, 7, 260-268.

[83] Pazhoohan, M., Arian, M., Ghorashi, M. and Khosrotehrani, K. (2014) A Study of Drainage Pattern Responses to Active Tectonics in Tadvan Region, SW Iran. Geodynamics Research International Bulletin, 1, 36-41.

[84] Rahimi, N. and Arian, M. (2014) Tectonic Geomorphplogy of Kangavar-Sosangerd Region, West Iran. Advances in Environmental Biology, 8, 119-124.

[85] Arian, M. and Hashemi, A. (2008) Seismotectonic Zoning in the Zagros. Journal of Sciences, 18, 63-76.

[86] Arian, M., Ahmadnia, A., Qorashi, M. and Pourkermani, M. (2002) Structural Analysis of Mengharak Transcurrent Fault System in Zagros, Iran. Special GEO 2002 Conference Issue Geoarabia, 7, 209-210.

[87] Arian, M., Qorashi, M., Pourkermani, M. and Ahmadnia, A. (2003) Fractal Analysis of Mengharak Transcurrent Fault System in Zagros, Iran. Proceedings of the 4th International Conference on Seismology and Earthquake Engineering, Tehran, 12-14 May 2003, 23.

[88] Baharvand, S., Pourkermani, M., Ajalloian, R., Arian, M. and Nouryazdan, A.R. (2010) Seymareh Landslide and Its Role in Environmental and Geomorphologic Changes of the Pole-Dokhtar Area. Journal of the Earth, 4, 13-24.

[89] Abdideh, M., Qorashi, M., Rangzan, K. and Arian, M. (2011) Assessment of Relative Active Tectonics Using Morphometric Analysis, Case Study of Dez River (Southwestern, Iran). Geosciences, 20, 33-46.

[90] Arian, M., Qorashi, M., Pourkermani, M. and Ahmadnia, A. (2006) The Structural Significance Kareh Bas Transcurrent Fault System in the Zagros Fold and Thrust Belt. Geosciences, 15, 126-133.

[91] Arian, M. and Noroozpour, H. (2015) Seismic Activity and Fractal Geometry of Kareh Bas Fault System in Zagros, South of Iran. Open Journal of Geology, 5, 291-299. http://dx.doi.org/10.4236/ojg.2015.55026

[92] Ehsani, J. and Arian, M. (2015) Quantitative Analysis of Relative Tectonic Activity in the Jarahi-Hendijan Basin Area, Zagros Iran. Geosciences Journal, 19, 751-765. http://dx.doi.org/10.1007/s12303-015-0016-3 
[93] Omidali, M., Arian, M. and Sorbi, A. (2015) Neotectonics of Boroujerd Area, SW Iran by Index of Active Tectonics. Open Journal of Geology, 5, 309-324. http://dx.doi.org/10.4236/ojg.2015.55028

[94] Chegini, A., Sorbi, A. and Arian, M. (2015) Active Tectonics of Hamedan Area, SW Iran by Index of Active Tectonics. International Journal of Geology, 4, 108-118.

[95] Maleki, Z., Arian, M., Solgi, A. and Ganjavian, M.A. (2014) The Elements of Fold Style Analysis in the Khaftar Anticline, Zagros, Iran. Open Journal of Geology, 4, 79-92. http://dx.doi.org/10.4236/ojg.2014.43008

[96] Maleki, Z., Arian, M. and Solgi, A. (2014) Structural Style and Hydrocarbon Trap of Karbasi Anticline, in the Interior Fars Region, Zagros, Iran. Solid Earth Discussions, 6, 2143-2167. http://dx.doi.org/10.5194/sed-6-2143-2014

[97] Ehsani, J., Arian, M. and Ghorashi, M. (2015) Geomorphic Signatures of Active Tectonics in the Jarahi-Hendijan Drainage Basin in the South West Iran. Geosciences, 24, 211-218.

[98] Khodabakhshnezhad, A., Pourkermani, M., Arian, M., Matkan, A.A. and Charchi, A. (2015) Active Tectonics of Great Karoun River Basin. Geosciences, 24, 13-28.

[99] Maleki, Z., Arian, M., Solgi, A. and Ganjavian, M.A. (2015) Elements of Fold Style Analysis in the Karbasi Anticline, Interior Fars Region, Zagros. Geosciences, 24, 293-302.

[100] Baratpour, F., Arian, M. and Solgi, A. (2015) Geometric Analysis of Tukak and Kamarun Anticlines on Izeh Zone, Zagros. Geosciences, 24, 191-200.

[101] GholamhoseinFard, N., Sorbi, A. and Arian, M. (2015) Active Tectonics of Kangavar Area, West Iran. Open Journal of Geology, 5, 422-441. http://dx.doi.org/10.4236/ojg.2015.56040

[102] Maleki, Z., Arian, M. and Solgi, A. (2015) Folding Pattern in the Fars Province, Zagros Folded Belt: Case Study on the Karbasi and Khaftar Anticlines, Interior Fars, Iran. Solid Earth Discussions, 7, 2347-2379. http://dx.doi.org/10.5194/sed-7-2347-2015

[103] Aram, Z. and Arian, M. (2016) Active Tectonics of the Gharasu River Basin in Zagros, Iran, Investigated by Calculation of Geomorphic Indices and Group Decision Using Analytic Hierarchy Process (AHP) Software. Episodes, 39, 39-44. http://dx.doi.org/10.18814/epiiugs/2016/v39i1/89235

[104] Abdolizadeh, S., Maleki, Z. and Arian, M. (2016) Earthquake Hazard Zonation and Seismotectonics of the Bandar Abbas Area, Zagros, Iran. Open Journal of Geology, 6, 210-224. http://dx.doi.org/10.4236/ojg.2016.63019

[105] Hadizadeh, A., Arian, M. and Ganjouyan, M.A. (2011) Analysis Geometry Dashtak Detachment Zone in the Dashtak, Salamati and Sepidar Anticlines from Interior and Sub Coastal Fars Area. Journal of the Earth, 6, 33-44.

[106] Khodabakhshnezhad, A., Arian, M. and Pourkermani, M. (2008) The Elements of Fold Style Analysis in the Asmari Anticline (Zagros). Journal of Sciences, 18, 129-138.

[107] Khodabakhshnezhad, A., Arian, M. and Pourkermani, M. (2015) Folding Mechanism in the Asmari Anticline, Zagros, Iran. Open Journal of Geology, 5, 197-208. http://dx.doi.org/10.4236/ojg.2015.54018

[108] Arian, M., Pourkermani, M., Khodabakhshnezhad, A. and Noroozpour, H. (2011) Investigation of Oil Trap in the Asmari Anticline (Zagros, Iran). Indian Journal of Science and Technology, 4, 1696-1699.

[109] Alladin, Y., Talebian, M., Arian, M. and Ahmadi, M.M. (2015) Geotechnical Investigation and Seismic Zonation of Alluvial Deposits in Western Tehran. Geosciences, 24, 333-342.

[110] Taherkhani, B., Nazari, H., Pourkermani, M. and Arian, M. (2015) Geometry and Recent Kinematics of the North Qazvin Fault: Morphotectonic Approach. Geosciences, 24, 29-38.

[111] Manuchehri, H., Arian, M., Ghorashi, M., Solgi, M. and Sorbi, A. (2015) Geomorphic Signatures of Active Tectonics in the Chalus Drainage Basin in the Alborz, Iran. Geosciences, 24, 273-280.

[112] Noroozpour, H., Arian, M. and Sorbi, A. (2015) Fault Movement Potentials in the Tehran-Semnan Region (North Iran) Open Journal of Geology, 5, 281-290. http://dx.doi.org/10.4236/ojg.2015.55025

[113] Arian, M., Maleki, Z. and Noroozpour, H. (2011) Cenozoic Diastrophism and Deformational Events in the East Central Alborz. Journal of Basic and Applied Scientific Research, 1, 2394-2400.

[114] Feizi, F., Arian, A. and Rahmani, R. (2007) Seismotectonic Zoning in the Eastern Part of the Central Alborz. Journal of Sciences, 17, 151-164.

[115] Khavari, R., Arian, M. and Ghorashi, M. (2009) Neotectonics of the South Central Alborz Drainage Basin, in NW Tehran, N Iran. Journal of Applied Sciences, 9, 4115-4126. http://dx.doi.org/10.3923/jas.2009.4115.4126

[116] Arian, M. and Bagha, N. (2012) Active Tectonics of Tehran Area, Iran. Journal of Basic and Applied Scientific Research, 2, 3805-3819.

[117] Bagha, N., Arian, M., Ghorashi, M., Pourkermani, M., El Hamdouni, R. and Solgi, A. (2014) Evaluation of Relative Tectonic Activity in the Tehran Basin, Central Alborz, Northern Iran. Geomorphology, 213, 66-87. http://dx.doi.org/10.1016/j.geomorph.2013.12.041 
[118] Arian, M. and Feizi, F. (2005) Application of Geomorphic Indices to the Assessment of Relative Tectonic Activity Levels in the Alborz-Central Iran Border Zone. Journal of Sciences, 15, 378-403.

[119] Arian, M., Bagha, N., Khavari, R. and Noroozpour, H. (2012) Seismic Sources and Neo-Tectonics of Tehran Area (North Iran). Indian Journal of Science and Technology, 5, 2379-2383.

[120] Moghimi, H., Arian, M. and Sorbi, A. (2015) Fault Movement Potential of Marzanabad Area, North Alborz, Iran. Open Journal of Geology, 5, 126-135. http://dx.doi.org/10.4236/ojg.2015.53012

[121] Arian, M. and Pourkermani, M. (2004) Tectonic Elements of South Flank in the East-Central Alborz Mountain. Journal of Sciences, Teacher Training University, 4, 359-368.

[122] Arian, M. and Qorashi, M. (2006) The Movement Potential Evaluation of the Major Quaternary Faults in Alborz-Central Iran Border Zone, from the East of Tehran to the East of Semnan. Journal of Geosciences, Geological Survey of Iran, 15, 184-188.

[123] Poroohan, N., Pourkermani, M. and Arian, M. (2013) An Assessment of Relationship in F-Parameter and Paleostress Fields in Heterogeneous Lithologies: Roudbar Area (Northwest of Iran). Australian Journal of Basic \& Applied Sciences, 7, 933-942.

[124] Poroohan, N., Poukermani, M. and Arian, M. (2009) An Assessment on Correlations of Seismotectonic Parameters Preceding and Following Roudbar-Manjil Earthquake (Gilan, North of Iran). Australian Journal of Basic \& Applied Sciences, 3, 2643-2652.

[125] Farrokhnia, A.R., Pirasteh, S., Pourkermani, M. and Arian, M. (2011) Geo-Information Technology for Mass Wasting Hazard Zonation: Central-West Alborz-Iran. Disaster Advances, 4, 24-33.

[126] Khavari, R., Ghorashi, M. and Arian, M. (2009) Assessment of Relative Active Tectonics, South Central Alborz (North Iran). EGU General Assembly Conference Abstracts, 11, 1137.

[127] Sorbi, A., Arian, M. and Pourkermani, M. (2009) The Movement Potential Evaluation of the Major Quaternary Faults in Tehran Quadrangle. Journal of the Earth, 19, 176-182.

[128] Feizi, F. and Arian, M. (2006) The Classification of Thrust Fronts in the Alborz-Central Iran Border Zone from the East of Varamin to the East of Semnan. Journal of Sciences, 16, 75-87.

[129] Razaghian, G. and Arian, M. (2015) The Emergent Salt Diapirs in the East Zagros, Iran. Open Journal of Geology, 5, 718-726.

[130] Arian, M. and Pourkermani, M. (2004) Structural Significance of North Semnan and Attary Faults in Alborz-Central Iran Border Zone. Journal of Sciences, 14, 4551-4569.

[131] Arian, M. and Pourkermani, M. (2005) Cenozoic Diastrophism and Deformational Events in the Southern Flank of Central-East Alborz. Journal of Faculty Earth Sciences, 10, 43-51.

[132] Sadeghi, R., Saeedi, A., Arian, M., Ghorashi, M. and Solgi, A. (2015) Comparison of Strain Ellipsoid Shape in the South of Ardabil Range (NW) Based on the Results of the Magnetic Susceptibility Anisotropy and Paleostress Methods. Open Journal of Geology, 5, 611-622. http://dx.doi.org/10.4236/ojg.2015.59054

[133] Arian, M., Pourkermani, M., Qorashi, M. and Ghasemi, M.R. (2003) North Semnan Fault System and Its Role on Basin Division. Proceedings of the 8th Symposium of Geological Society of Iran, Shahrood, 4-6 September 2003, 11-17.

[134] Pourkermani, M. and Arian, M. (2001) Structural Geomorphology of Northeastern Kurdistan. Journal of Humanities, 7, $37-48$.

[135] Mardani, Z., Ghorashi, M. and Arian, M. (2011) Geomorphic Signatures of Active Tectonics in the Talaghanrud, Shahrudand Sefidrud Drainage Basins in Central Alborz, N Iran. Geosciences, 20, 159-166.

[136] Sorbi, A., Arian, M. and Pourkermani, M. (2011) The Application of Geomorphic Indices to the Assessment of Relative Tectonic Activity Levels in Tehran Quadrangle. Journal of the Earth, 6, 1-9.

[137] Khavari, R., Ghorashi, M., Arian, M. and Khosrotehrani, K. (2010) Geomorphic Signatures of Active Tectonics in the Karaj Drainage Basin in South Central Alborz, N Iran. Geosciences, 19, 67-74.

[138] Mousavi, E.J. and Arian, M. (2015) Tectonic Geomorphology of Atrak River, NE Iran. Open Journal of Geology, 5, 106-114. http://dx.doi.org/10.4236/ojg.2015.53010

[139] Nouri, R., Jafari, M.R., Arian, M., Feizi, F. and Afzal, P. (2013) Correlation between Cu Mineralization and Major Faults Using Multifractal Modelling in the Tarom Area (NW Iran) Geologica Carpathica, 64, 409-416. http://dx.doi.org/10.2478/geoca-2013-0028

[140] Nouri, R., Jafari, M.R., Arian, M., Feizi, F. and Afzal, P. (2013) Prospection for Copper Mineralization with Contribution of Remote Sensing, Geochemical and Mineralographical Data in Abhar 1:100,000 Sheet, NW Iran. Archives of Mining Sciences, 58, 1071-1084. http://dx.doi.org/10.2478/amsc-2013-0074

[141] Nouri, R., Afzal, P., Arian, M., Jafari, M. and Feizi, F. (2013) Reconnaissance of Copper and Gold Mineralization Us- 
ing Analytical Hierarchy Process in the Rudbar 1:100,000 Map Sheet, Northwest Iran. Journal of Mining and Metallurgy, 49, 9-19.

[142] Farrokhnia, A.R., Pirasteh, S., Pradhan, B., Pourkermani, M. and Arian, M. (2011) A Recent Scenario of Mass Wasting and Its Impact on the Transportation in Alborz Mountains, Iran Using Geo-Information Technology. Arabian Journal of Geosciences, 4, 1337-1349. http://dx.doi.org/10.1007/s12517-010-0238-7

[143] Arian, M. and Nouri, R. (2015) Lineament Tectonics and Mineralization in Tarom Area, North Iran. Open Journal of Geology, 5, 115-124. http://dx.doi.org/10.4236/ojg.2015.53011

[144] Feizi, F. and Arian, M. (2011) The role of Structural Controllers in Geneses of Copper Deposits in 1:50000 Map of Saiin Qaleh. Journal of Sciences, 21, 1-10.

[145] Arian, M., Qorashi, M. and Ahmadnia, A. (2003) Analysis of Behbahan Shear Zone. Iranian Journal of Geology, 1, 1-4.

[146] Bahiraee, S., Arian, M., Qorashi, M. and Solgi, M. (2015) The Movement Potential Evaluation of the Mosha Fault (The West of Firoozkuh to the Shahrestanak). Geosciences, 24, 123-126.

[147] Bagha, N., Ghorashi, M., Arian, M., Pourkermani, M. and Solgi, A. (2015) Neotectonic Analysis of Mosha-North Tehran Fault Zone, Based on Morphotectonic Features, Central Alborz, Northern Iran. Geosciences, 24, 41-52.

[148] Mosavi, E. and Arian, M. (2015) Neotectonics of Kashaf Rud River, NE Iran by Modified Index of Active Tectonics (MIAT). International Journal of Geosciences, 6, 776-794. http://dx.doi.org/10.4236/ijg.2015.67063

[149] Nouri, R. and Arian, M. (2015) Structural Control on the Distribution of Hydrothermal Alteration Zones and Mineralization in Dastjerdeh Area Based on Remote Sensing Data, NW Iran. Bulletin of the Georgian National Academy of Sciences, 9, 79-86.

[150] Khosroshahizadeh, S., Pourkermani, M., Almasiyan, M., Arian, M. and Khakzad, A. (2015) Evaluation of Structural Patterns and Related Alteration and Mineralization Zones by Using ASAR-ASTER Imagery in Siyahrood Area (East Azarbaijan—NW Iran). Open Journal of Geology, 5, 589-610. http://dx.doi.org/10.4236/ojg.2015.59053

[151] Sistanipour, A. and Arian, M. (2015) Geometric Analysis of Davaran Fault System, Central Iran. Open Journal of Geology, 5, 458-469. http://dx.doi.org/10.4236/ojg.2015.56043

[152] Nazemi, M., Ghorashi, M., Ghassemi, M.R. and Arian, M. (2015) Morphotectonics Features of Alluvial Fans Associated with Active Tectonics (Shotori Mountains, East of Tabas-Central Iran). Geosciences, 24, 91-100.

[153] Alizadeh, H. and Arian, M. (2015) Rule of Structural Factors in Formation of Porphyry Copper Deposits in South Western Part of Kerman Area, Iran. Open Journal of Geology, 5, 489-498. http://dx.doi.org/10.4236/ojg.2015.57045

[154] Mosavi, E.J. and Arian, M. (2015) Neotectonics of Tabas Area, Central Iran by Index of Active Tectonics (IAT). Open Journal of Geology, 5, 209-223. http://dx.doi.org/10.4236/ojg.2015.54019

[155] Daryani, N.J., Arian, M. and Omran, N.R. (2015) Tectonics and Mineralization of Copper in the Ardestan-Kahang Area, Central Iran by Remote Sensing. Open Journal of Geology, 5, 188-196. http://dx.doi.org/10.4236/ojg.2015.54017

[156] Arian, M. and Pourkermani, M. (2001) Rivers Morphology and Active Tectonic (Reviewing the Current Status of Ghezel Ozon River in the Province of Zanjan). Proceedings of the 5th Conference of Geological Society of Iran, Tehran, 28-30 August 2001, 556.

[157] Arian, M., Toudeshki, V.H. and Noroozpour, H. (2011) Active Tectonics of Qezel Ozan River Basin, NW Iran. Journal of Applied Environmental and Biological Sciences, 1, 291-295.

[158] Alizadeh, H., Arian, M., Lotfi, M., Ghorashi, M. and Ghorbani, M. (2015) Determination of Porphyry Copper Deposit Locations Using Photo Lineament Factor in Northern Parts of the Dehaj-Sardoiyeh Belt. Geosciences, 24, $247-252$.

[159] Toudeshki, V.H., Pourkermani, M., Arian, M. and Khosrotehrani, K.H. (2011) Influence of Structures on the Ghezel Ozan River. Geosciences, 21, 55-60.

[160] Toudeshki, V.H. and Arian, M. (2011) Morphotectonic Analysis in the Ghezel Ozan River Basin, NW Iran. Journal of Geography and Geology, 3, 258-260. http://dx.doi.org/10.5539/jgg.v3n1p258

[161] Arian, M. (2015) Seismotectonic-Geologic Hazards Zoning of Iran. Earth Sciences Research Journal, 19, 7-13. http://dx.doi.org/10.15446/esrj.v19n1.40664

[162] Arian, M., Pourkermani, M., Sistanipour, A. and Noroozpour, H. (2011) Kinematic Significance of Fold- and FaultRelated Fracture Systems in the Rafsanjan's Northeast Highlands (Central Iran). Journal of Basic and Applied Scientific Research, 1, 3398-3406.

[163] Arian, M., Pourkermani, M., Sistanipour, A. and Noroozpour, H. (2011) Seismicity and Fault Segmentation of BafqBaghin Fault System (Central Iran). Journal of Applied Environmental and Biological Sciences, 1, 382-396.

[164] Arian, M. (2010) Earthquake-Fault Hazard Investigations in the Kerman Quadrangle. Journal of Sciences, 19, $176-182$.

[165] Arian, M. and Sorbi, A. (2011) Remote Sensing Investigation of the Faults and Lineaments in the Karaj-Qazvin Region. Journal of the Earth, 5, 21-34. 
[166] Arian, M., Alizadeh, H. and Noroozpour, H. (2011) Satellite Geometry of Faults and Fractures and Its Relationship with Porphyry Deposits in Northern Parts of Dahaj-Sardoiyeh Belt, South of Iran. Indian Journal of Science and Technology, 4, 1303-1306.

[167] Mosavi, E.J., Arian, M., Ghorashi, M. and Nazemi, M. (2012) Measurements of Geomorphic Indices in Tabas Area. Journal of the Earth, 7, 213-225.

[168] Eshghi, Z., Arian, M. and Pourkermani, M. (2012) Structural Investigation on the Lak Mining Area (Bueen Zahra) Based on Remote Sensing, Used for Its Mineralization. Journal of the Earth, 6, 145-155.

\section{Submit or recommend next manuscript to SCIRP and we will provide best service for you:}

Accepting pre-submission inquiries through Email, Facebook, LinkedIn, Twitter, etc.

A wide selection of journals (inclusive of 9 subjects, more than 200 journals)

Providing 24-hour high-quality service

User-friendly online submission system

Fair and swift peer-review system

Efficient typesetting and proofreading procedure

Display of the result of downloads and visits, as well as the number of cited articles

Maximum dissemination of your research work

Submit your manuscript at: http://papersubmission.scirp.org/ 